\title{
KONSEP MANTRA PENGOBATAN MASYARAKAT SUKU KOKODA DAN MANFAATNYA BAGI PENDIDIKAN BAHASA
}

\author{
Abdul Hafid ${ }^{1}$, Teguh Yuliandri Putra ${ }^{2}$ \\ Program Studi Pendidikan Bahasa Indonesia \\ Universitas Pendidikan Muhammadiyah Sorong ${ }^{1,2}$ \\ $\underline{\text { hafidabdul363@yahoo.co.id }}{ }^{1}$
}

Submit, 24-01-2019 Accepted, 17-04-2019 Publish, 23-04-2019

\begin{abstract}
ABSTRAK
Penelitian ini bertujuan untuk menjelaskan struktur dalam mantra pengobatan dalam masyarakat suku Kokoda, menjelaskan fungsi dalam mantra pengobatan masyarakat suku Kokoda, menjelaskan temuan pragmatis mantra pengobatan bagi pendidikan bahasa. Penelitian ini menggunakan pendekatan kualitatif. Lokasi penelitian dilakukan di suku Kokoda Kabupaten Sorong. Informan penelitian terdiri dari dua informan utama, dan dua informan pendamping. Teknik pengumpulan data menggunakan teknik observasi, wawancara, dan dokumentasi. Teknik analisis data menggunakan teknik analisis model interaktif Miles dan Huberman. Hasil penelitian, berdasarkan hasil analisis data ditemukan 1) struktur mantra pengobatan suku Kokoda beragam dan tidak teratur. 2) fungsi mantra pengobatan suku Kokoda adalah fungsi kekuatan magis yaitu digunakan untuk menyembuhkan berbagai macam penyakit. 3) temuan pragmatis mantra pengobatan masyarakat suku Kokoda dapat dijadikan sebagai sumber bahan ajar mata pelajaran bahasa Indonesia. Simpulan, struktur mantra pengobatan masyarakat suku Kokoda terdiri empat larik sampai sembilan larik. Struktur mantra pengobatan suku Kokoda dibagi menjadi dua macam yakni mantra sempurna dan mantra tidak sempurna.Mantra pengobatan suku Kokoda memiliki fungsi kekuatan magis yaitu digunakan untuk menyembuhkan berbagai macam penyakit, fungsi menyampaikan pesan adalah mengajarkan manusia tentang adanya kekuatan yang bersifat mistik, tolong menolong, menempati janji, menghormati guru, kepatuhan kepada Tuhan dan rasul-Nya, hubungan sosial, dan tidak bersikap sombong, fungsi identitas sosial adalah konstruksi yang dibagun oleh masyarakat pengguna mantra.
\end{abstract}

Kata Kunci: Mantra Pengobatan, Struktur, Fungsi, Pengajaran Bahasa

\section{ABSTRACT}

The research aims at explaining the structure and the function of treatment spell in Kokoda community as well as explaining the pragmatic function of treatment spell in language education. The research was a qualitative research. It was conducted in Kokoda community, Sorong regency. The informants consist of two main informants and two supporting informants. The techniques in collecting the data were observation, interview and doccumentation. The data were analyzed through interactive model by Miles and Huberman. The findings were 1) the treatment spell was various and unstructured 2) the function of the treatment spell was magical, means can cure any diseases 3) pragmatic finding showed that the spell can bebas teaching resource in 
Indonesian language. In conclusion, the structure of the spell consist of four to nine lines. It classified into perfect spell and imperfect spell. It has magic function to cure disease; messages delivery function to teach humans about magic, love to help, empathy, respecting teachers, obeying God and the prophets, social relationship, humble; social identity function as the construction built by the community of spell users.

Keyword: Treatment Spell, Structure, Function, Language Teaching

\section{PENDAHULUAN}

Keberadaan tradisi lisan di tengah-tengah masyarakat Indonesia yang telah memiliki budaya tulis yang cukup pesat seperti sekarang ini memposisikan sastra lisan dalam dua kondisi. Pertama sastra lisan masih tetap bertahan di tengah pergeseran zaman yang semakin pesat. Kedua, sastra lisan di ambang kepunahan, karena sudah banyak ditinggalkan oleh masyarakat pemiliknya. (Nengsih, 2017) sastra lisan sudah banyak ditinggalkan di era modern digantikan oleh sastra tulis yang lebih menarik dan kekinian.

Salah satu bentuk sastra lisan yang klasik adalah mantra. Mantra dapat dikategorikan dalam sastra lisan berbentuk puisi rakyat. Mantra sebagai salah satu genre sastra lisan, pada masanya dijadikan masyarakat pemiliknya sebagai suatu soslusi dari permasalahan-permasalahan kehidupan, sehingga mantra bukan hanya bersifat estetik tetapi juga bersifat pragmatik. (Setiadi \& Firdaus, 2018). Salah satu bukti mantra dapat dijadikan sebagai solusi kehidupan adalah ketika pemilik mantra mengalami kesulitan maka akan membacakan mantra untuk menimbulkan trans (Nugraha, 2018).

Mantra adalah puisi dengan bentuk pengulangan kata dan bunyi-bunyi interjeksi, sehingga menampilkan nada dan irama yang kuat. Apabila dibaca berulangulang maka akan menimbulkan perasaan tertentu, seperti khusuk, magis, bahkan semacam trans (Glosarium: 1.250 Entri Kajian Sastra, Seni, dan Sosial Budaya, 2013). Mantra adalah sastra yang eksklusif, pembacaan dan teksnya bersifat khusus dan terikat, lafalnya tidak jelas, memiliki kekuatan magis, dan ada akibat nyata atas pelaksanaannya (Amir, 2013).

Salah satu masyarakat yang kaya akan khazanah budaya adalah masyarakat suku Kokoda Kabupaten Sorong yang memiliki kekayaan budaya daerah, adat istiadat, kesenian yang sangat banyak. Salah satunya adalah sastra lisan (mantra) yang tumbuh dan berkembang sejak zaman dahulu dan diwariskan secara turun temurun. Salah satu 
mantra yang sangat terkenal pada masyarakat Kokoda adalah mantra pengobatan. Mantra pengobatan digunakan oleh masyarakat suku Kokoda untuk tujuan tertentu (special purpose), yaitu untuk mengobati berbagai macam penyakit.

Pengobatan dengan media mantra masih tetap bertahan dan digunakan oleh masyarakat suku Kokoda sampai sekarang. Akan tetapi, mantra pengobatan sangat sedikit diminati dan diwariskan kepada generasi muda, sehingga keberadaan mantra akan terancam punah pada masa yang akan datang. Kondisi ini relevan dengan pendapat (Candra, Noviyanti, \& Nurlaily, 2018) karya sastra, khususnya mantra sangat kurang diminati oleh generasi muda. Salah satu bentuk mempertahankan keberadaan mantra pengobatan suku Kokoda adalah dengan cara melakukan penelitian dan publikasi.

Penelitian tentang mantra sebenarnya sudah banyak dilakukan diantranya penelitian (Sorayah, 2014) dengan judul "Fungsi dan Makna Mantra Tandur di Desa Karangnunggal Kecamatan Cibeber Kabupaten Cianjur”. Fungsi mantra tandur ialah sebagai penyampai pesan (pendidikan), sebagai alat pencerminan masyarakat, dan sebagai identitas kebudayaan. Makna mantra tandur ialah sebagai media tersirat permohonan untuk memperoleh kebahagiaan hidup. Persamaan penelitian Sorayah dengan penelitian ini sama-sama meneliti tentang fungsi mantra. Perbedaannya adalah peneliti Sorayah meneliti tentang mantra tandur (menanam padi) dan makna mantra, sedangkan penelitian ini meneliti mantra pengobatan, dan aspek pragmatis mantra.

Penelitian lain tentang mantra adalah penelitian yang dilakukan oleh (Fatmawaty, Chusna, \& Taufiqurrahman, 2017) menyatakan struktur cowongan merupakan urutan-urutan ritual dan prosesi sebelum pembacaan mantra, kemudian pembaca mantra. Mantra ini sangat sarat dengan makna kasih sayang dan belas kasih kepada Tuhan dan sesama mahluk Tuhan. Persamaannya dengan penelitian ini adalah sama-sama meneliti struktur mantra, sedangkan perbedaanya penelitian Fatmawaty, Chusna, dan Taufiqurrahman meneliti ritual cowongan (mantra memanggil hujan), sedangkan penelitian ini meneliti mantra pengobatan, fungsi, dan aspek pragmatis.

\section{METODE PENELITIAN}

Penelitian ini menggunakan pendekatan kualitatif. Pendekatan kualitatif digunakan dalam penelitian ini karena objek penelitian yang bersifat alamiah. Pendekatan kualitatif adalah pendekatan yang digunakan untuk meneliti objek yang 
alamiah, peneliti adalah instrumen kunci dalam penelitian, menggunakan teknik triangulasi, analisis data induktif, serta untuk menghubungkan masalah dengan fenomena menggunakan logika ilmiah (Sugiono, 2010). Metode yang digunakan metode deskripsi. Menurut (Nazir, 2009) metode deskripsi adalah metode yang digunakan dalam meneliti status sekelompok manusia, suatu objek, suatu set kondisi, atau sistem pemikiran, atau suatu kelas peristiwa.

Tempat penelitian ini dilakukan di suku Kokoda Kabupaten Sorong. Informan dalam penelitian ini terdiri dari dua informan utama dan dua informan pendamping. Teknik pengumpulan data yang digunakan adalah observasi, wawancara, studi dokumentasi. Metode analisis data menggunakan model interaktif Miles and Huberman. Adapun langkah-langkah analisis data yang dilakukan adalah melakukan pengumpulan data, reduksi data, penyajian data, dan tahap penyimpulan (Miles dan Huberman, 1992).

\section{HASIL PENELITIAN}

Penelitian ini difokuskan pada struktur, fungsi dan temuan pragmatis mantra pengobatan suku Kokoda.

\section{Struktur Mantra Pengobatan Suku Kokoda}

Hasil penelitian ini ditemukan empat mantra pengobatan suku Kokoda. Keempat mantra tersebut adalah mantra menurunkan panas, mantra segala penyakit, mantra kunci diri, dan mantra luka. Struktur mantra pengobatan masyarakat suku Kokoda adalah mantra menurunkan panas terdiri empat larik, mantra segala penyakit terdiri dari lima larik, mantra kunci diri terdiri dari sembilan larik, dan mantra luka terdiri dari enam larik.. Bahasa yang digunakan adalah bahasa Kokoda, bahasa Arab (Alquran). Struktur mantra pengobatan suku Kokoda secara garis besar dapat dibagi menjadi dua macam yakni mantra sempurna dan tidak sempurna. Mantra sempurna adalah mantra yang terdiri dari unsur pembuka, isi, dan penutup (mantra kunci diri), sedangkan mantra tidak sempurna yang tidak memiliki kelengkapan unsur seperti mantra menurunkan panas yang hanya terdiri dari unsur pembuka dan isi, kemudian mantra segala penyakit dan mantra luka yang hanya terdiri dari unsur isi saja. 


\section{Fungsi Mantra Pengobatan Suku Kokoda}

Mantra pengobatan suku Kokoda memiliki beberapa fungsi diantaranya fungsi kekuatan magis. Fungsi kekuatan magis yang dimaksudkan dalam konteks ini adalah sesuai dengan tujuan pembacaan mantra. Dalam penelitian ini tujuan pembacaan mantra adalah untuk menyebuhkan beberapa jenis penyakit, maka hasilnya adalah penyembuhan penyakit sesuai dengan mantra yang dibacakan. Kesembuhan itu didapatkan karena adanya kekuatan magis yang terdapatkan dari bunyi-bunyi (mantra) yang dibacakan.

Fungsi keimanan, pengguna mantra pengobatan suku Kokoda harus memiliki kepercayaan yang totalitas terhadap mantra. Kepercayaan yang di dalamnya tidak ada keraguan sedikit pun. Kepercayaan terhadap semua bunyi-bunyian yang ada di dalam mantra, walaupun konsep yang terdapat di dalam mantra tersebut bersifat irasional dan tidak relevan dengan ilmu medis.

Mantra pengobatan suku Kokoda juga memiliki fungsi untuk menyampaikan pesan. Adapun pesan yang disampaikan dalam mantra pengobatan suku Kokoda sebagai berikut: 1) mengajarkan manusia tentang adanya kekuatan yang bersifat mistik (supranatural), 2) mengajarkan kepada manusia untuk saling tolong menolong, 3) mengajarkan manusia untuk menempati janji, 4) mengajarkan tentang ketaatan dan kepatuhan terhadap guru (menghormati guru), 5) mengajarkan pentingnya kepatuhan kepada Tuhan dan rasul-Nya. Pentingnya menjaga hubungan dengan sesama manusia, roh nenek moyang, dan alam, 6) mengajarkan kepada manusia untuk tidak bersikap sombong dan takabur. Fungsi mantra pengobatan suku Kokoda yang terakhir adalah fungsi sebagai identitas sosial. Fungsi sebagai identitas sosial lebih mengarah pada konstruksi yang dibangun oleh masyarakat terhadap seseorang yang memiliki mantra pengobatan.

\section{Temuan Pragmatis bagi Pendidikan Bahasa}

Berdasarkan hasil kajian tentang struktur, dan fungsi mantra pengobatan suku Kokoda ditemukan aspek pragmatis yang dapat diterapkan dalam pendidikan dan pengajaran. Adapun temuan pragmatis dari penelitian ini dapat diajarkan di SMP dan SMA atau sederajat karena, isi mantra pengobatan suku Kokoda mengandung unsur 
Kompetensi Inti dalam kurukulum 2013 yakni sikap spritual, sikap sosial, pengetahuan, dan keterampilan.

\section{PEMBAHASAN}

\section{Struktur Mantra Pengobatan Suku Kokoda}

Struktur memiliki eksistensi yang cukup penting dalam karya sastra (mantra), karena tanpa adanya struktur, maka karya sastra tersebut tidak mungkin akan terbentuk. Menurut (Badrun, 2014) struktur merupakan satu kesatuan yang utuh, saling berhubungan, yang kesemuanya memberikan nilai sastra yang tinggi. Adapun struktur mantra pengobatan suku Kokoda sebagai berikut.

\section{Struktur mantra menurunkan panas}

\section{Bismilahirrahmanirrahim}

Nedi namama

Nedi Apato

Timagito paru parua

Artinya

Dengan menyebut nama Allah Yang Maha Penyasih lagi Maha Penyayang

ini badan saya

Ini darah saya

Hancur penyakit

Mantra pengobatan di atas terdiri dari empat larik. Larik pertama terdiri dari satu kata. Larik kedua terdiri dari dua kata. Larik ketiga juga terdiri dari dua kata, sedangkan larik keempat terdiri dari tiga kata. Apabila dilihat dari segi bentuk, mantra penyakit menurunkan panas di atas merupakan mantra tidak sempurna, karena hanya terdiri dari bagian pembuka dan isi. Bahasa yang digunakan adalah bahasa Arab (Alquran) dan bahasa Kokoda.

\section{Mantra segala penyakit}

Timagito tana gomo mua watae tana maira

Timagito moria awenenuто тиа timagito tukae awenenu maira

Timagito moria tahiagomo watae taimaira

Timagito moria inetagomo watae ineta maira

Dimeredo timagito mua moria watae dimeredo maira

Artinya

Penyakit yang datang dari tanah kembali ke tanah

Penyakit dari angin, penyakit engkau kembali ke angin

Penyakit dari air kembali ke air 
Penyakit dari api kembali ke api

Penyakit yang datang dari orang mati kembali ke orang mati

Mantra di atas terdiri dari lima larik. Larik pertama terdiri dari tujuh kata, larik kedua terdiri dari delapan kata, larik ketiga terdiri dari lima kata, larik keempat terdiri dari enam kata, sedangkan larik kelima terdiri dari tujuh kata. Ditinjau dari segi bentuk mantra ini merupakan mantra tidak sempurna karena hanya terdiri dari bagian isi. Semuanya isi mantra menggunakan bahasa Kokoda.

\section{Mantra kunci diri}

Assalamualaikum tana

Assalamualaikum bumi

Bismillahirrahmanirrahim

Ashaduallah Ilaha Ilallah

Waashaduanna Muhammaddarasululullah

Ashaduallah Ilaha Ilallah

Waashaduanna Muhammaddarasululullah

Ashaduallah Ilaha Ilallah

Waashaduanna Muhammaddarasululullah

Artinya

Semoga keselamatan untuk tanah

Semoga keselamatan bumi

Dengan menyebut nama Allah yang Maha Mengasih lagi Maha Penyayang

Aku bersaksi tiada Tuhan selain Allah

dan aku bersaksi bahwa Muhammad utusan Allah

Aku bersaksi bahwa tiada Tuhan selain Allah dan aku bersaksi bahwa Muhammad utusan Allah

Aku bersaksi tiada bahwa Tuhan selain Allah dan aku bersaksi bahwa Muhammad utusan Allah

Mantra kunci diri di atas terdiri dari sembilan larik. Larik pertama terdiri dari dua kata, larik kedua juga terdiri dari dua kata, larik ketiga terdiri dari satu kata, larik keempat, enam, dan delapan terdiri dari dua kata, sedangkan larik kelima, tujuh, serta sembilan terdiri dari tiga kata. Dari segi bentuk mantra ini unik dan berbeda dengan mantra yang lain karena bahasa yang lazim digunakan sebagai unsur pembuka digunakan dalam tiga ciri. Pertama, menggunakan pembuka horizontal yang menggabungkan pembuka dengan isi dalam satu larik ditandai dengan larik pertama dan kedua. Kedua, penggunaan pembuka horizontal ditandai dengan larik yang ketiga. Ketiga, penggunaan larik pembuka yang berada diantara isi dan penutup. Dalam mantra 
kunci diri semua unsur mantra terpenuhi yakni pembuka, isi, dan penutup sehingga dikategorikan sebagai mantra sempurna.

Adanya unsur yang tidak berurutan dalam mantra, dibenarkan secara ilmiah karena mantra memiliki ciri-ciri yang sama dengan puisi baru dan puisi kontemporer. Persamaannya adalah puisi lama dalam bentuk mantra dengan puisi baru dan puisi kontemporer sama-sama termasuk puisi bebas, karena tidak memiliki patokan atau aturan tertentu. Hal ini sesuai dengan pendapat (Sutopo, 2014) mantra termasuk puisi bebas, karena tidak berpatokan pada aturan tertentu, baik jumlah kata, bunyi, atau barisnya. Unsur yang terpenting dalam mantra adalah konteksnya, artinya paham waktu atau tempat dalam mengucapkannya. Bahasa yang digunakan dalam mantra ini menggunakan bahasa Kokoda dan bahasa Arab (Alquran).

\section{Mantra Luka}

Tomuka tao mode bojaraba

Igina tao mode bojaraba

Igina babukomo bodaraba

Igina mamaya bodaraba

Igina tokomo bodaraba

Igina tutukumu bodaraba

Artinya

Saya melayani orang yang luka

Saya melayani dengan air untuk menyembuhkan luka

Saya melayani tubuh yang sakit

Saya melayani dengan air untuk menyembuhkan tubuh yang sakit

Saya melayani dengan air untuk menyembuhkan tulang yang sakit

Saya melayani dengan untuk menyembuhkan air urat yang sakit.

Mantra luka terdiri dari enam larik. Larik pertama dan kedua terdiri dari empat kata, sedangkan larik ketiga sampai larik keempat terdiri dari tiga kata. Mantra luka ini mengandung nilai yang estetik karena semua larik berima akhir vokal a-a. Mantra luka dari aspek struktur merupakan mantra tidak sempurna karena hanya terdiri dari bagian isi. Bahasa yang digunakan semuanya menggunakan bahasa Kokoda. Semua struktur 
bahasa dalam mantra pengobatan suku Kokoda termasuk mantra luka tidak bisa diubah, karena bukan hanya mengurangi nilai estetik tetapi juga mengurangi nilai mistik dalam penggunaan mantra. Apabila diubah secara pragmatis mantra yang dibacakan tidak memiliki fungsi praktis apapun (menyembuhkan penyakit).

\section{Fungsi Mantra Pengobatan Suku Kokoda}

Karya sastra apapun bentuk dan jenisnya, bukan hanya mengandung nilai estetis tetapi juga bermanfaatkan bagi penikmatnya. Karya sastra juga memiliki manfaat atau fungsi yang tidak dapat dikesampingkan baik untuk penikmat sastra secara pribadi maupun secara kolektif. Hal ini sesuai dengan pendapat (Wellek dan Warren, 2014) setiap karya seni (satra) "manis" sekaligus "bermanfaat" bagi setiap penikmatnya: bahwa perenungan yang diberikan oleh sastra lebih dasyat dari pada perenungan yang dilakukan sendiri oleh maing-masing penikmat seni. Adapun fungsi mantra pengobatan suku Kokoda adalah sebagai berikut.

\section{Fungsi Kekuatan Magis}

Fungsi yang fundamental dalam mantra adalah fungsi magis. Setiap mantra, termasuk mantra pengobatan suku Kokoda tidak bisa dilepaskan pada fungsi magis. Munurut (Noormaidah, 2017) salah satu fungsi mantra adalah kekuatan magis melalui doa-doa, baik secara langsung maupun dengan perantara. Fungsi kekuatan magis dalam mantra pengobatan masyarakat suku Kokoda disesuaikan dengan jenis mantra pengobatan tersebut yakni mantra menurunkan panas untuk mengobati sakit panas, mantra segala penyakit untuk mengobati berbagai jenis penyakit, mantra kunci diri untuk menjaga diri supaya tidak terkena penyakit, dan mantra luka untuk menyembuhkan luka.

Kesembuhan tersebut didapatkan karena adanya kekuatan magis yang terdapatkan dari bunyi-bunyi (mantra) yang dibacakan. Karena konteksnya adalah mantra pengobatan, kekuatan magis yang ditimbulkan dari pembacaan mantra adalah kekuatan yang mendamaikan dan menyembuhkan penyakit. (Ismawati, 2017) karya sastra bukan hanya mempunyai fungsi filosofis, tetapi solusi dari permasalahan yang mendamaikan. 


\section{Fungsi Keimanan}

Keimanan dan kepercayaan terhadap bunyi-bunyian dalam mantra adalah syarat mutlak dan totalitas yang bersifat absolut supaya mendapatkan fungsi-fungsi mantra yang lain. (Rukesi \& Sunoto, 2017) salah satu aspek penting dalam mantra adalah hubungan pembaca mantra dengan Tuhan (keimanan yang totalitas)

Pengguna mantra pengobatan suku Kokoda harus memiliki kepercayaan yang totalitas terhadap mantra. Kepercayaan yang di dalamnya tidak ada keraguan sedikit pun. Kepercayaan terhadap semua bunyi-bunyian yang ada di dalam mantra, walaupun konsep yang terdapat di dalam mantra tersebut bersifat irasional dan tidak relevan dengan ilmu medis. (Yahya, 2016) pengguna mantra sangat percaya dengan kekuatan gaib yang ada di dalam mantra. Sama dengan mantra pengobatan suku Kokoda yang merupakan susunan kata-kata mengandung kekuatan gaib. Apabila pengguna mantra tidak memiliki kepercayaan yang totalitas, maka mantra yang dibacakan tidak akan memiliki dampak apapun (tidak dapat menyembuhkan penyakit). Hal ini relevan dengan pendapat (Tiwi \& Rara, 2013) salah satu syarat mantra adalah pembaca mantra harus memiliki kepercayaan terhadap kekuatan sakti (gaib dan irasional), apabila tidak memiliki kepercayaan yang totalitas, maka mantra tidak memiliki dampak apapun. Ini merupakan antitesa dari pendapat (Nursalim \& Tiana, 2018) mantra hanyalah sebuah bagian dari karya sastra yang di dalamnya menyimpan makna dan tentu tidak ada unsur magis.

\section{Fungsi Menyampaikan Pesan}

Karya sastra mengandung pesan-pesan moral yang dapat memperbaiki karakter individu dan sosial (Effendy, 2018). Salah satu fungsi mantra pengobatan masyarakat suku Kokoda adalah fungsi menyampaikan pesan. (Iskandar, 2016) sastra berisi petunjuk, nasehat, dan amanat yang harus dilaksanakan agar dapat menjalani hidup dengan baik. Adapun fungsi mantra pengobatan masyarakat suku Kokoda sebagai berikut.

1. Mengajarkan manusia tentang adanya kekuatan yang bersifat mistik (supranatural), kekuatan kata-kata atau bunyi-bunyi yang apabila dilafalkan dengan kepercayaan dan keyakinan yang totalitas akan menimbulkan efek tertentu (kesembuhan dan kedamaian). Kekuatan yang bersifat mistik dapat membawa nilai-nilai dan 
kebahagiaan bagi orang yang mempercayainya. (Prastika, 2017), kekuatan mistik bukan hanya untuk mencapai kebahagiaan, tetapi juga sebagai spirit spiritual. (Nugraha, 2018) kandungan pengetahuan dalam mantra bersifat luar nalar.

2. Mengajarkan kepada manusia untuk saling tolong menolong antara satu dengan yang lainnya dengan menggunakan mantra sebagai media pengobatan untuk orang lain. Menurut (Setiadi \& Firdaus, 2018) mantra sebagai salah satu genre sastra lisan, pada masanya dijadikan masyarakat

Nusantara sebagai jawaban dalam menangani permasalahan kehidupan. Pendapat ini relevan dengan konteks kehidupan sosial masyarakat Kokoda yang sampai saat ini masih mempertahankan eksistensi mantra, yang difungsikan untuk menolong orang yang sakit (tolong menolong).

3. Mengajarkan manusia untuk menempati janji. Fungsi menempati janji diajarkan dalam mantra melalui syarat-syarat yang harus dipenuhi dalam penggunaan mantra.

4. Mengajarkan tentang ketaatan dan kepatuhan terhadap guru (menghormati guru). Ketaatan kepada guru dalam konteks ini adalah mempercayai dengan totalitas terhadap bunyi-bunyi yang diajarkan oleh guru. Memenuhi syarat-syarat yang disampaikan oleh guru dalam menggunakan mantra.

5. Mengajarkan pentingnya kepatuhan kepada Tuhan dan rasul-Nya. Pentingnya menjaga hubungan dengan sesama manusia, roh-roh nenek moyang, mahluk Tuhan yang lain: angin, api, air, tanah, tumbuh-tumbuhan, binatang, batu, dan sebagainya).

6. Mengajarkan kepada manusia untuk tidak bersikap sombong dan takabur terhadap mantra yang dimiliki.

\section{Fungsi sebagai Identitas Sosial}

Mantra pengobatan masyarakat suku Kokoda juga memiliki fungsi sebagai identitas sosial. Fungsi sebagai identitas sosial lebih mengarah pada konstruksi yang dibangun oleh masyarakat terhadap sesorang yang memiliki mantra pengobatan. Oleh karena itu, fungsi sebagai identitas sosial merupakan proses budaya, penghargaan yang diberikan oleh masyarakat kepada orang yang memiliki mantra pengobatan. 


\section{Temuan Pragmatis bagi Pendidikan Bahasa}

Berdasarkan hasil kajian tentang struktur, dan fungsi mantra pengobatan suku Kokoda ditemukan aspek pragmatis yang dapat diterapkan dalam pendidikan dan pengajaran, khusunya mata pelajaran bahasa Indonesia di SMP/MTs., SMA/MA/SMK sederajat. Adapun temuan pragmatis tersebut dapat dilihat dalam bagan berikut.

KI (Sikap)

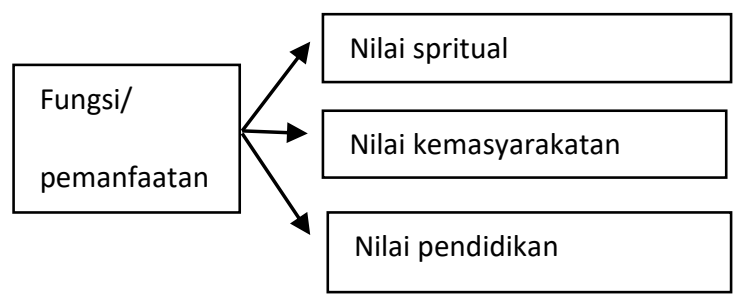

KI (Pengetahuan)

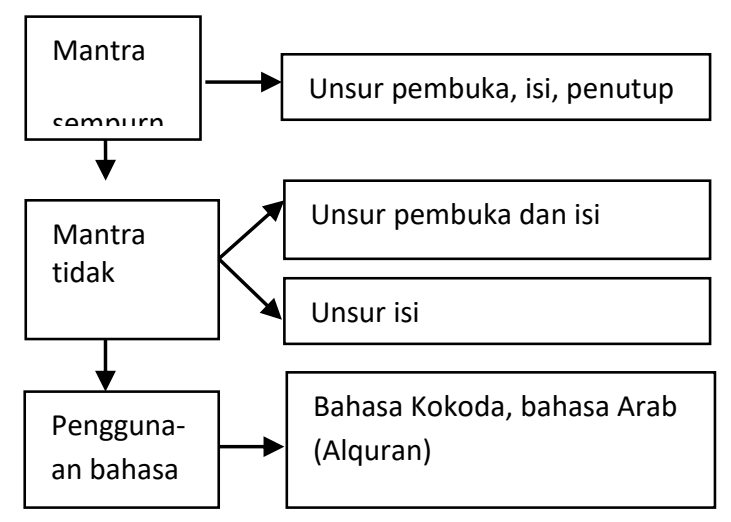

KI (Keterampilan)

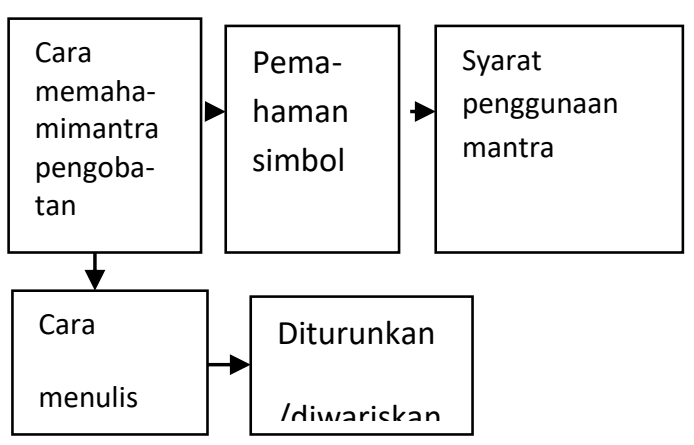




\section{SIMPULAN}

Berdasarkan hasil dan pembahasan di atas, dapat disimpulkan bahwa struktur, fungsi, dan temuan pragmatis penelitian mantra pengobatan masyarakat suku Kokoda sebagai berikut. Struktur mantra pengobatan masyarakat suku Kokoda terdiri empat larik sampai sembilan larik. Menggunakan bahasa Kokoda, bahasa Arab (Alquran). Struktur mantra pengobatan suku Kokoda dibagi menjadi dua macam yakni mantra sempurna dan mantra tidak sempurna. Mantra pengobatan suku Kokoda memiliki fungsi kekuatan magis yaitu digunakan untuk menyembuhkan berbagai macam penyakit. Fungsi memperkuat keimanan yaitu mempercayai kekuatan mantra. Fungsi menyampaikan pesan adalah mengajarkan manusia tentang adanya kekuatan yang bersifat mistik, tolong menolong, menempati janji, menghormati guru, kepatuhan kepada Tuhan dan rasul-Nya, hubungan sosial, dan tidak bersikap sombong. Fungsi identitas sosial adalah konstruksi yang dibagun oleh masyarakat pengguna mantra. Temuan pragmatis mantra pengobatan masyarakat suku Kokoda dapat dijadikan sebagai sumber bahan ajar mata pelajaran bahasa Indonesia. 


\section{DAFTAR PUSTAKA}

Andi Muhammad Yahya. (2016). Kajian Jenis, Fungsi, dan Makna Mantra Bugis Desa Tanjung Samalantakan (A Study Of Types, Functions, And Meanings Buginese Mantras Of Tanjung Samalantakan Village). Jurnal Bahasa, Satra, dan Pembelajarannya.

Amir A. (2013). Sastra Lisan Indonesia. Yogyakarta: Andi.

Badrun, A. (2014). Sruktur, Makna, Fungsi dan Proses Pembuatan Patu Mbojo, Mataram: Lengge.

Candra, K., Noviyanti, L. P. E., \& Nurlaily, K. (2018). Pemaknaan dan Transmisi Mantra Tri Sandhya Pada Remaja Hindu Bali Di Daerah Malang. Jurnal Poetika

Effendy, C. (2018). Peranan Sastra dan Bahasa Melayu alam Membangun Karakter Bangsa. Jentera: Jurnal Kajian Sastra.

Fatmawaty, L. S. W. A., Chusna, A., \& Taufiqurrahman, M. (2017). Struktur dan Makna dalam Ritual Memanggil Hujan (Cowongan) di Banyumas. In Prosiding Seminar Nasional dan call for Papers "Pengembangan Sumber Daya Perdesaan dan Kearifan Lokal Berkelanjutan VII.”

Iskandar, I. (2016). Bentuk, Makna, dan Fungsi Pappaseng dalam Kehidupan Masyarakat Bugis di Kabupaten Bombana. Jurnal Bastra dan Bastra.

Ismawati, E. (2017). Mantra Bumi Karya Aprinus Salam sebagai Bahan Ajar Apresiasi Sastra. Makalah PIBSI Undip.

Miles, M.B. dan Huberman, A.M. (1992). Analisis Data Kualitatif. Terjemahan T.R. Rohidi, Jakarta: Universitas Indonesia.

Nazir, M. (2009). Metode Penelitian. Bogor: Gralia Indonesia.

Noormaidah. (2017). Kajian Jenis, Fungsi, dan Makna Mantra Bakumpai (Types, Functions, and Meaning Analysis of Bakumpai Mantras). Jurnal Bahasa, Satra, dan Pembelajarannya.

Nugraha, F. I. (2018). Mantra Bandung Bondowoso sebagai Tindak Tutur. Jurnal Ilmiah FONEMA: Jurnal Edukasi Bahasa dan Sastra Indonesia. https://doi.org/10.25139/fn.v1i2.1177

Nursalim, M. P., \& Tiana, R. (2018). Penerapan Semiologi Barthes pada Mantra Tukang Pijit. Dialektika: Jurnal Bahasa, Sastra, dan Pendidikan Bahasa dan Sastra Indonesia. https://doi.org/10.15408/dialektika.v5i1.6120

Prastika, N. (2017). Yoga Sastra Laku Mistik Balian Usada Bali. DHARMASMRTI. 
Ratna, N. K. (2013). Glosarium: 1.250 Entri Kajian Sastra, Seni dan Sosial Budaya, Yogyakarta: Pustaka Pelajar.

Rukesi, R., \& Sunoto, S. (2017). Nilai Budaya dalam Mantra Bercocok Tanam Padi di Desa Ronggo, Kecamatan Jaken, Kabupaten Pati, Jawa Tengah: Kajian Fungsi Sastra. BASINDO: Jurnal Kajian Bahasa, Sastra Indonesia, dan Pembelajarannya. https://doi.org/10.17977/um007v1i12017p025

Setiadi, D., \& Firdaus, A. (2018). Teks Mantra Embeung Beurang Seputar Kehamilan dan Kelahiran Bayi di Cidolog Kabupaten Sukabumi. Paramasastra: Jurnal Ilmiah Bahasa Sastra dan Pembelajarannya. https://doi.org/10.26740/parama.v1i2.1489

Sorayah, Y. (2014). Fungsi dan Makna Mantra Tandur di Desa Karangnunggal Kecamatan Cibeber Kabupaten Cianjur. Bahtera Sastra: Antologi Bahasa dan Sastra Indonesia.

Sutopo, S. (2014). Sastra Indonesia Lama Mutiara yang Kaya Wacana, Yogyakarta: Aura Pustaka.

Sugiyono (2010). Metode Penelitian Kuantitatif, Kualitatif Dan $R$ \& D. Bandung: Alfabeta.

Tiwi, \& Rara, E. K. (2013). Kajian Struktur dan Fungsi Mantra Pangesti Luhur dalam Ritual Pencarian Berkah di Sendhang Boto Rubuh. SKRIPSI Jurusan Sastra Indonesia - Fakultas Sastra UM.

Wahyu Nengsih, S. (2017). Keunikan Bahasa Mantra Banjar: Panah Arjuna (The Uniqueness of the Expression of Banjarese Spell:Panah Arjuna). Metasastra: Jurnal Penelitian Sastra. https://doi.org/10.26610/metasastra.2013.v6i2.115-124

Wellek, Rene., dan Austin Warren. (2014). Teori Kesusastraan. Jakarta: Gramedia PustakaUtama. 